\title{
editorial
}

\section{A Request for Controversial Opinions}

The Editor has often heard the comment that there should be more controversial material in the Forestry Chronicle. However, only very rarely do foresters who make such comments actually write down their controversial views. D. H. Pimlott from the Department of Zoology at the University of Toronto in a dinner speech given at the Ontario Professional Foresters Association in November 1967 made the following points on deficiencies which he considers to be plaguing the forestry profession in Canada. These were as follows:

"1. The profession assiduously avoids facing the most important issues of the day;

2. Although foresters are often at the nub of political controversy, they fail to comprehend how political processes work; fail to comprehend how public interest could work to their advantage.
3. The philosophy of the profession is far too narrow for the profession to assume leadership in the new era of multiple use that is dawning in Canada.

He has particularly castigated Ontario foresters for their lack of expressed opinion during the period 1954-1964 on the question of forest regeneration in Ontario. He claims that in no profession have boat rockers been more discouraged than in the profession of forestry."

There are many vital issues concerning Canada's forests, their regeneration, management, multiple use, problems of pollution, etc. This editorial is an invitation to those few boat rockers in the profession of forestry field to write for the Forestry Chronicle. The only restrictions are that their opinions should be informed ones and be brief.

G. F. WEETMAN 